\title{
CONCENTRATIONS OF CERTAIN HEAVY METALS IN IMPORTED FROZEN FISH IN EGYPT
}

\author{
Ahmed EI Nemr \\ Environmental Division, National Institute of Oceanography and \\ Fisheries, Kayet Bay, Alexandria, Egypt
}

Keywords: Imported frozen fish, heavy metals, pollution, ingestion fish, hazard index, Egypt

\begin{abstract}
Concentrations of nine heavy metals $(\mathrm{Cd}, \mathrm{Co}, \mathrm{Cr}, \mathrm{Cu}, \mathrm{Fe}, \mathrm{Mn}, \mathrm{Ni}$, $C_{P d}$ and $\mathrm{Zn}$ ) were determined in imported frozen fish namely Mackerel (Scomber scombrus): "Striped red mullet (Mullus surmuletus), Groster argentine (Argentina silus), Commen pandora (Pagellus erythinzus) and Atlantic horse mackerel (Trachurus trachurus). The average concentrations of the heavy metals analyzed exhibited the following decreasing order: $\mathrm{Fe}>\mathrm{Zn}>\mathrm{Pb}>\mathrm{Co}>\mathrm{Cu}>$ $\mathrm{Cr}>\mathrm{Mn}>\mathrm{Ni}>\mathrm{Cd}$. The concentrations of the studied heavy metals in fish tissues were lower than the Effect Range-Low (ERL) for such fish, while gill and liver exhibited elevation over the ERL for Cd only. The metal pollution index (MPI) for most studied fish fluctuated between 0.90 and 4.42 with average 2.18 for wet weight. The ingestion of heavy metals and the calculated lifetime daily intake have been reported and do not represent any actual risk due to the low concentrations of heavy metals in the studied fish tissues. These results suggest that the studied imported frozen fish might be considered as unpolluted with heavy metal.
\end{abstract}

\section{INTRODUCTION}

The past three decades have witnessed an increased awareness of problems concerning food pollution. Among them, the heavy metals are one of the most persistent and accumulative pollutants. They are natural constituents of earth crust, thus, heavy metals pollution describes elevated concentrations in different environmental compartments to a level that is detrimental to living organisms (Robert, 1991). Human beings are exposed to heavy metals via polluted air, water and food. 
Cadmium has no biological function in human system and it is potentially toxic even at trace concentrations (Rbert, 1991). Kidneys are the critical target following long term exposure to cadmium, in addition to hepatotoxicity, skeletal impairment and neurotic effects (Misara et al., 1998). Cadmium induced hepatic and renal injury in chronically exposed rats, likely role of hepatic cadmiummetallothionein in nephrotoxicity (Dudley et al., 1982 and 1985). Cadmium intoxication can lead to oxidative damage in tissues by enhancing per-oxidation of cell membrane lipids and altering the antioxidant defense armory of the cells (Gupta et al., 1991; Bagchi et al., 1996). Severe contamination with cadmium had led to itai-itai disease (Yosumura et al., 1980).

Accumulation of copper in liver leads to cirrhosis; in brain can lead to death of neurons with neurological symptoms; and in kidney leads to renal tubular damage (Forstner and Wittmann, 1983; Matta et al., 1999).

Nickel acetate depresses circulating antibody titers (Figoni and Treagan, 1975) to T-phages and inhibits the interferon response of metal treated cells (Treagan and Furst, 1970). Nickel also inhibits the phagocytic ability and other properties of macrophages (Graham et al., 1975). Delayed hypersensitivity reactions occur in guinea pigs that are exposed to nickel (Parker and Turk, 1978). Lead exerts adverse effects on the resistance of the body to disease. It also suppresses the immune system, particularly the humoral response in animals. This suppression often occurs at very low sub-clinical dosages and, therefore, may be detrimental to the health of animals and perhaps of man by mechanisms other than the typical welldocumented toxicity which occurs at larger dosages. Severe contamination with $\mathrm{Pb}$ leads to brain damage, anemia, liver, and kidney diseases (Rippe and Berry, 1973; Goyer and Mushak, 1977).

The contamination of the near-shore marine environment and food chain by heavy industries is common in many developed and developing countries. This phenomenon is not only of major public concern, but may pose potential risks to human health through the consumption of contaminated seafood. Industrial wastes, geochemical structure and mining of metals create a potential source of heavy metal pollution in the aquatic environment (Lee and Stuebing, 1990; Gumgum et al., 1994). Under certain environmental conditions, heavy metals may accumulate to a toxic concentration (Guven et al., 1999), and cause ecological damage (Harms, 1975; Jefferies and Freestone, 1984; Freedman, 1989). 
The present study was carried out to determine the levels of nine heavy metals ( $\mathrm{Cd}, \mathrm{Co}, \mathrm{Cr}, \mathrm{Cu}, \mathrm{Fe}, \mathrm{Mn}, \mathrm{Ni}, \mathrm{Pb}$ and $\mathrm{Zn}$ ) in muscle (tissue), liver, and gill of five imported frozen fish namely: Mackerel (Scomber Scombrus), Striped red mullet (Mullus surmuletus), Groster argentine (Argentina silus), Commen pandora (Pagellus erythrinus) and Atlantic horse mackerel (Trachurus trachurus). These fish species are commonly consumed as a popular diet in Egypt, specially for the average income people (Tables 1 and 2).

\section{MATERIAL AND METHODS}

Specimens of five of the imported fish namely: Mackerel (Scomber. Scombris), Striped red mullet (Mullus surmuletus), Groster argentine (Argentina silus), Commen pandora (Pagellus erythrinus) and Atlantic horse mackerel (Trachurus trachurus) (Table 2) were collected from a fish market in Alexandria in January, 2003. Selection of samples was based on relative abundance and availability due to the wide array of imported species and sources of supply. From each species; eight fish were obtained, packed in ice and brought to the laboratory on the same day. Samples tissues, gill and liver of each species were dissected using clean equipment and put separately in petridishes and transferred into an oven set to $70^{\circ} \mathrm{C}$ to dry. Drying continued until all the wet tissues reached to a constant weight. Dry samples (triplicate each $0.4 \mathrm{~g}$ ).were put into digestion flasks followed by addition of $8 \mathrm{ml}$ nitric acid (Merck), $3 \mathrm{ml}$ perchloric acid and heated at $80^{\circ} \mathrm{C}$ : until all the materials were dissolved. After digestion, samples were diluted. with deionized water, filtered and completed using deionized water to $25 \mathrm{ml}$. . The resulting solutions were analyzed using flame atomic absorption spectrophotometer (AAS) (Perkin Elmer, Model 2380). The results were expressed in $\mathrm{mg} \mathrm{kg}^{-1}$ dry wt. (UNEP/FAO/IAEA/IOC, 1984). The absorption wavelength and detection limits were as follows: $228.8 \mathrm{~nm}$ and $0.06 \mathrm{mg} \mathrm{kg}^{-1}$ for $\mathrm{Cd} ; 240.7 \mathrm{~nm}$ and $0.05 \mathrm{mg} \mathrm{kg}^{-1}$ for $\mathrm{Co} ; 357.9 \mathrm{~nm}$ and $0.06 \mathrm{mg} \mathrm{kg}^{-1}$ for $\mathrm{Cr} ; 324.7 \mathrm{~nm}$ and $0.06 \mathrm{mg} \mathrm{kg}^{-1}$ for $\mathrm{Cu} ; 248.3 \mathrm{~nm}$ and $0.8 \mathrm{mg} \mathrm{kg}^{-1}$ for $\mathrm{Fe} ; 279.5 \mathrm{~mm}$ and $0.07 \mathrm{mg} \mathrm{kg}^{-1}$ for $\mathrm{Mn} ; 232.0 \mathrm{~nm}$ and $0.09 \mathrm{mg} \mathrm{kg-}$ for $\mathrm{Ni} ; 217.0 \mathrm{~nm}$ and $0.8 \mathrm{mg} \mathrm{kg}^{-\mathrm{i}}$ for $\mathrm{Pb} ; 213.9 \mathrm{~nm}$ and $0.7 \mathrm{mg} \mathrm{kg}^{-1}$ for $\mathrm{Zn}$, respectively.

Reagents of analytical grade were utilized for the blanks and calibration curves. Precision was checked against standard reference material, provided by the National Research Council of Canada 
(DORM-1 for dogfish) and lied within the range of certified values with $94 \sim 99 \%$ recovery for all metals studied.

To prevent contamination, all used glass and plastic labware were previously washed in dilute nitric acid and deionized water.

Metal concentrations are reported as per dry weight of tissue and because metal pollution index (MPI) is measured as "per wet weight of tissue", the MPI calculation was performed by transforming all values to per wet weight values. These were calculated by dividing the dry values by 5 , the wet/dry weight of most tissues.

\section{RESULTS AND DISCUSSION}

The determined levels of nine heavy metals in imported frozen fish samples are presented in Table 3. The concentrations of heavy metals followed the decreasing order of $\mathrm{Zn}>\mathrm{Fe}>\mathrm{Pb}>\mathrm{Co}>$ $\mathrm{Cr}>\mathrm{Cu}>\mathrm{Ni}>\mathrm{Mn}>\mathrm{Cd}$ in Mackerel tissues; and $\mathrm{Fe}>\mathrm{Zn}>\mathrm{Co}>\mathrm{Pb}$ $>\mathrm{Cr}>\mathrm{Mn}>\mathrm{Ni}>\mathrm{Cu}>\mathrm{Cd}$ in Mackerel gill; and $\mathrm{Zn}>\mathrm{Fe}>\mathrm{Cu}>\mathrm{Pb}>$ $\mathrm{Co}>\mathrm{Cd}>\mathrm{Cr}>\mathrm{Mn}>\mathrm{Ni}$ in Mackerel liver. The heavy metal levels in Striped red mullet tissues were: $\mathrm{Fe}>\mathrm{Zn}>\mathrm{Co}>\mathrm{Pb}>\mathrm{Mn}>\mathrm{Cr}>$ $\mathrm{Cu}>\mathrm{Cd}>\mathrm{Ni}$; in gills $\mathrm{Fe}>\mathrm{Zn}>\mathrm{Pb}>\mathrm{Co}>\mathrm{Cr}>\mathrm{Mn}>\mathrm{Cu}>\mathrm{Ni}>\mathrm{Cd}$; and in liver $\mathrm{Fe}>\mathrm{Zn}>\mathrm{Cu}>\mathrm{Pb}>\mathrm{Cr}>\mathrm{Co}>\mathrm{Mn}>\mathrm{Cd}>\mathrm{Ni}$. The same heavy metal concentrations in tissues of Groster argentine were: $\mathrm{Zn}>\mathrm{Fe}>\mathrm{Co}>\mathrm{Cu}>\mathrm{Cr}>\mathrm{Mn}>\mathrm{Pb}>\mathrm{Ni}>\mathrm{Cd}$; in gills $\mathrm{Zn}>\mathrm{Fe}>\mathrm{Co}$ $>\mathrm{Pb}>\mathrm{Cr}>\mathrm{Mn}>\mathrm{Cu}>\mathrm{Ni}>\mathrm{Cd}$; and in liver $\mathrm{Fe}>\mathrm{Zn}>\mathrm{Cu}>\mathrm{Co}>\mathrm{Pb}$ $>\mathrm{Cr}>\mathrm{Mn}>\mathrm{Cd}>\mathrm{Ni}$. Heavy metal concentrations in tissues of Commen pandora were: $\mathrm{Zn}>\mathrm{Fe}>\mathrm{Pb}>\mathrm{Cr}>\mathrm{Mn}>\mathrm{Ni}>\mathrm{Cu}>\mathrm{Cd}>$ $\mathrm{Co}$; in gill $\mathrm{Fe}>\mathrm{Zn}>\mathrm{Pb}>\mathrm{Mn}>\mathrm{Co}>\mathrm{Cr}>\mathrm{Ni}>\mathrm{Cu}>\mathrm{Cd}$; and in liver $\mathrm{Zn}>\mathrm{Fe}>\mathrm{Cd}>\mathrm{Cu}>\mathrm{Pb}>\mathrm{Co}>\mathrm{Cr}>\mathrm{Mn}>\mathrm{Ni}$. Heavy metal concentrations in tissues of Atlantic horse mackerel were: $\mathrm{Fe}>\mathrm{Zn}>$ $\mathrm{Co}>\mathrm{Pb}>\mathrm{Cr}>\mathrm{Cu}>\mathrm{Mn}>\mathrm{Cd}>\mathrm{Ni}$; in gills $\mathrm{Fe}>\mathrm{Zn}>\mathrm{Pb}>\mathrm{Co}>\mathrm{Cr}$ $>\mathrm{Ni}>\mathrm{Mn}>\mathrm{Cu}>\mathrm{Cd}$; and in liver $\mathrm{Fe}>\mathrm{Zn}>\mathrm{Pb}>\mathrm{Co}>\mathrm{Cu}>\mathrm{Cd}>$ $\mathrm{Mn}>\mathrm{Ni}>\mathrm{Cr}$.

These results showed that $\mathrm{Ni}$ had a low tendency to accumulate in the liver for all studied fish than accumulation of $\mathrm{Pb}$. Cadmium was found to accumulate in liver for most studied fish several times more than in gills and tissues. Copper was found accumulating in liver than $\mathrm{Pb}$ in most studied fish except Atlantic horse mackerel. According to Tolonen (1995), in vertebrates, the highest concentrations of copper were found in liver, muscle, blood, head, and brain. 
Cadmium concentrations in the studied fish ranged from 0.33 to 66 in tissues. 0.33 to 1.31 in gill and 1.64 to 29.2 in liver, with average concentration of $3.5 \pm 7.42 \mathrm{mg} \mathrm{kg}^{-1}$ dry weight. Cadmium. concentrations were elevated in liver collected from Mackerel and Commen Pandora, while the tissues of all studied fish samples exhibited no significant elevation of cadmium. However, cadmium accumulating in liver, gill, kidney, rather than in muscle, may be replacing zinc in some enzymes, and has a long half-life time (10-30 years) (Kotsonis and Klaassen, 1977 and 1978). In this study, cadmium concentrations in tissues were higher than the maximum acceptable limits reported by EPA (1995) but less than that reported by both CEFAS (1997) and NHMRC (1987) (Table 4).

Copper was the third most abundant element for all studied samples, and the highest concentration of copper was found in Mackerel liver $27.16 \mathrm{mg} \mathrm{kg}^{-1}$ dry weight, while the lowest one was found in Commen pandora tissue and gill $1.94 \mathrm{mg} \mathrm{kg}^{-1}$ dry weight. The highest concentration of copper reported in this study was less than the ERL ( $34 \mathrm{mg} \mathrm{kg}^{-1}$ dry weight) and less than the maximum acceptable limits by MAFF (1956) $100 \mathrm{mg} \mathrm{kg}^{-1}$ (Table 4).

Iron concentrations ranged from 15.18 to 41.73 in tissue; 79.67 to 284.54 in gill and 159.34 to 887.77 in liver with average value $177.3 \pm 217.86 \mathrm{mg} \mathrm{kg}^{-1}$ dry weight. The highest iron concentration was found in liver of the Atlantic horse mackerel, while the lowest concentration was found in tissue of Commen pandora. Concentrations of iron in liver may be influenced by the amount of blood retained in tissue and therefore depends, in part, on the length of time between death of the fish and collection of the tissues (Thompson, 1992). As the fish in this study was imported frozen fish, this will ensure that iron from liver tissues is measured rather than from the blood.

Zinc is the second most abundant element for all studied samples, which accumulates with concentrations comparable to accumulation of iron. According to Law et al. (1992), the concentration of zinc in the liver rariged between 80 and $400 \mathrm{mg} \mathrm{kg}^{-1}$. Zinc concentrations in the liver of Mackerel were much higher than in liver of other fishes. The highest concentration of zinc was 389.73 $\mathrm{mg} \cdot \mathrm{kg}^{-1}$. dry weight as reported in Mackerel and the lowest one was found in Atlantic horse mackerel $\left(12.73 \mathrm{mg} \mathrm{kg}^{-1}\right.$ dry weight) with an average concentration of $89.95 \pm 100.11 \mathrm{mg} \mathrm{kg}^{-1}$ dry weight. The highest concentration recorded in this study was lower than ERM 
(410 $\mathrm{mg} \mathrm{kg}^{-1}$ dry weight) and lesser than the maximum acceptable limits by NHMRC (1987) (750 $\mathrm{mg} \mathrm{kg}^{-1}$ ).

Lead concentrations in this study were ranging between 4.75 and $23.86 \mathrm{mg} \mathrm{kg}^{-1}$ with average concentration of $12.85 \pm 5.33 \mathrm{mg} \mathrm{kg}^{-1}$ dry weight, which is lower than the ERL $\left(46.7 \mathrm{mg} \mathrm{kg}^{-1}\right.$ ). Lead was the third abundant metal accumulating in tissues following the iron and zinc. The highest concentrations of lead were found in gills followed by liver in most studied samples. The concentrations of $\mathrm{Pb}$ in this study were lower than the maximum acceptable limits recorded by BOE (1991) (25 $\mathrm{mg} \mathrm{kg}^{-1}$ ) (Table 4).

Manganese concentrations ranged between 2.57 to $10.28 \mathrm{mg}$ $\mathrm{kg}^{-1}$ with average concentration of $5.57 \pm 2.26 \mathrm{mg} \mathrm{kg}^{-1}$. This study, showed more accumulation of manganese in gills than in both tissues and liver. According to Thompson (1992), manganese concentrations in marine mammals are normally found in concentrations lower than $28 \mathrm{mg} \mathrm{kg}^{-1}$ in any tissue.

Cobalt concentrations were fluctuating between non-detected to $17.27 \mathrm{mg} \mathrm{kg}^{-1}$, with average concentration of $11.98 \pm 3.33 \mathrm{mg} \mathrm{kg}^{-1}$. Chromium concentrations were ranging between non-detected to $10.76 \mathrm{mg} \mathrm{kg}^{-1}$ with average concentration of $7.47 \pm 2.19 \mathrm{mg} \mathrm{kg}^{-1}$. Chromium was more accumulated in gills than in tissues and liver for most studied samples. Nickel concentrations were ranged from nondetected to $8.1 \mathrm{l} \mathrm{mg} \mathrm{kg} \mathrm{m}^{-1}$, with average concentration of $4.73 \pm 2.85$ $\mathrm{mg} \mathrm{kg} \mathrm{k}^{-1}$.

The overall metal content of imported frozen fishes were compared using the metal pollution index (MPI) calculated according to Usero et al.. (1996); Usero et al. (1997) where

$\mathrm{MPI}=(\mathrm{Cd} \times \mathrm{Co} \times \mathrm{Cr} \times \mathrm{Cu} \times \mathrm{Fe} \times \mathrm{Mn} \times \mathrm{Ni} \times \mathrm{Pb} \times \mathrm{Zn})^{1 / 9}$

The final MPI of each site is a weight mean value, as it was obtained taking into account the total weight of fish. The calculated MPI was fluctuating between 0.9 and 4.42 with an average value of $2.18 \pm 1.01$. The higher MPI were recorded for liver for all studied fish, while the lowest MPI was found in fish tissues.

\section{HUMAN HEALTH RISK ASSESSMENT}

The human health risk assessment has been calculated for the studied fish, depending on the calculation made by Albering et al. (1999).

Ingestion of fish $(\mathrm{IF})\left(\mathrm{mg} \mathrm{kg}^{-1} \mathrm{day}^{-1}\right)=(\mathrm{CF} \times \mathrm{IRF} \times \mathrm{FI} \times \mathrm{AF}) \div \mathrm{BW}$ 


\section{Calculated lifetime daily intake (CLTDI) $\left(\mathrm{mg} \mathrm{kg}^{-1} \mathrm{day}^{-1}\right)$ $=\left[\left(6 \times \mathrm{IF}_{\text {child }}\right) \div 70\right]+\left[\left(64 \times \mathrm{IF}_{\text {aduit }}\right) \div 7\right]$}

Hazard index $=$ CLTDI $\div$ tolerable daily intake (TDI) Where $\mathrm{CF}=$ concentration of the heavy metal contaminant in fish $\left(\mathrm{mg} \mathrm{kg}^{-1}\right.$ wet weight); $3 R F=$ ingestion rate of fish $(0.015$ and $0.055 \mathrm{~kg}$ wet weight/day for child and adult, respectively); FI = fraction contaminated ( 0.5 for both child and adult); $\mathrm{AF}=$ absorption factor $(1$ for both child and aduit) and BW $=$ Body weight ( 15 and $70 \mathrm{~kg}$ for child and adult. respectively); the TDIs for heavy metals could be derived from Bockting et al. (1996).

The calculation of fish ingestion, lifetime daily intake (e.g. 70 years) and hazard index had been reported in Table 5. The concentrations of heavy metals recorded for imported frozen fish tissues are still low, which gave the ingestion of fish very low values. These values were multiplied by $10^{-5} \mathrm{mg} \mathrm{kg}^{-1}$ day $^{-1}$, which gave low calculated lifetime daily intake (CLTDI) values, and therefore gave low hazard index values for all studied frozen fish tissues. The hazard index values were lesser than 1 for all studied samples, indicating no health risk on the consumers.

\section{CONCLUSION}

This study showed that heavy metal concentrations in the imported frozen fish were so far considerably lower than the ERL and lower than the maximum permissible levels for different countries. The calculations of risk assessment showed no possible health risk from the present heavy metals due to imported fish consumption.

\section{REFERENCES}

Albering, H. J. : Rila, J. P. ; Moonen, E. J. C. ; Hoogeweff, J. A. ; Kleinjans. J. C. S. (1999). Human health risk assessment in relation to environmental pollution of two artificial freshwater lakes in the Netherlands, 107:27-35.

Bagchi, D. ; Bagchi, M. ; Hassoun, E. A. ; Stohs, S. J. (1996). Cadmium induced excretion of urinary lipid metabolites, DNA damage, glutathione depletion and hepatic lipid peroxidation in SpragueDawley rats. Biol. Trace Elem. Res., 52: 143-154. 
Bockting, G. J. M. ; Koolenbrander, J. G. M. ; Swartjes, F. A. (1996). SEDISOIL. Estimation of human exposure to sediments [in Dutch]. Rpt no 715810011. Bilthoven, the Netherlands: National Institute of Public Health and the Environment.

BOE. (Boletin Oficial del Estado or Official Gazette of the State) (1991). Normas microbiôlogicas, limites de contenido en metales pesados y métodos analiticos para la determinacién de metales pesados para los productos de la pesca y de la agricultura (Microbio-logical standards, limits of heavy metal concentration, and analytical methods for the determination of heavy metals in fish and agricultural produce. August 2 Order. Madrid, Spain: Ed. BOE; 5937-5941.

CEFAS, (Centre for Environment, Fisheries and Aquaculture Science) (1997). Monitoring and surveillance of non-radioactive contaminants in the aquatic environment and activities regulating the disposal of waste at sea, 1994. Aquatic Environnent Monitoring Report 47 Lowestoft, UK: Centre for Environment. Fisheries, and Agriculture Science.

Dudley, R. E. : Gammal, L. M. ; Klassen, C. D. (1985). Cadmiuminduced hepatic and renal injury in chronically exposed rats: likely role of hepatic and cadmium-metallothionein in nephrotoxicity. Toxicol. Appl. Pharmacol., 77: 414-426.

Dudley, R. E. ; Svoboda, D. J. ; Klaassen, C. D. (1982). Acute exposure to cadinium causes severe liver injury in rats. Ibid., 65: 302313.

EEC, (European Economic Community) (1979). Council Directive 79/923/EEC of 30 Oct. 1979 on the quality required of shellfish waters. Luxembourg: Official Publications of the European Communities. OJ L281, 10 Nov. 1979.

EPA, (Environmental Protection Agency) (1995). Arsenic-Freshwater Human Health Criterion for fish Consumption, USA.

Figoni, R. ; Treagan, L. (1975). Inhibition effect of nickel and chromium upon antibody response of rats to immunization with T-1 phage. Res. Commun. Chem. Path. Pharmac., II: 335-338. 
Forstner. U. : Wittmann, T. W. (1983). Metal pollution in the aquatic Environment. Springer-Verlag, Berlin Heidelberg, New York, Tokyo. pp 30-61.

Freedman, B. (1989). The impacts of pollution and other stresses on ecosystem structure and function. Environmental Ecology. Academic press, London.

Graham, J. A. : Gardner, D. E. ; Waters, M. D. ; Coffin, D. C. (1975). Effect of heavy metals on phagocytosis by alveolar macrophages. Infec. Immun., 11: 1278.

Goyer, R. A. ; Mushak, P. (1977). Toxicology of heavy elements. Hemisphere Publishing corporation Washington, London, pp 123-126.

Gumgun, M. ; Unlu, E. ; Tez, Z. ; Gulsun, Z. (1994). Heavy metal pollution in water, sediment and fish from the Tigris River in Turkey. Chemosphere, 29(1): 111-116.

Gupta, S. ; Athar, M. ; Behari, J. R. ; Srivastava, R. C. (1991). Cadmium-mediated induction of cellular defence mechanism: a novel example for the development of adaptive response against a toxicant. Ind. Health, 29: 1-9.

Guven, K. ; Ozbay, C. ; Unlu, E. ; Satar, A. (1999). Aute lethal toxicity and accumulation of copper in Gammarus pulex (L.) (Amphipoda). Tr. J. Biol., 23: 511-521.

Harms, U. (1975). The levels of heavy metals (Mn, $\mathrm{Fe}, \mathrm{Co}, \mathrm{Ni}, \mathrm{Cu}, \mathrm{Zn}$, $\mathrm{Cd}, \mathrm{Pb}, \mathrm{Hg}$ ) in fish from onshore and offshore waters of the German bight. Z. Lebensm. Unters. Forsch, 157:125-130.

Jefferies, D. J.: Freestone, P. (1984). Chemical analysis of some coarse fish from a Suffolk River carried out as part of the preparation from the first release of captive-bred otters. J. Otter Trust, 1(8): 17-22.

Kotsonis, F. N. : Klaassen, C. D. (1977). Toxicity and distribution of cadmium administered to rats at sublethal doses. Toxicol. Appl. Pharmacol., 41: 667-680. 
Kotsonis, F, N. : Klaassen, C. D. (1978). The relationship of metallothionein to the toxicity of cadmium after prolonged oral administration to rats. Ibid., 46: 3 9-54.

Law, R. J. ; Jones, B. R. ; Baker, J. R. ; Kennedy, S. ; Milne, R. ; Morris, R. J. (1992). Trace metals in the livers of marine mammals from the Welsh coast and the Irish Sea. Marine Mammology, 15: 123-142.

Lee, Y. H. ; Stuebing, R. B. (1990). Heavy metal contamination in River Toad. Buffo juxtasper (Inger), near a copper mine in East Malaysia. Bull. Environ. Contam. Toxicol., 45:272-279.

MAFF, (Ministry of Agriculture, Fisheries and Food) (1956). Report on copper: Revised recommendations for limits for copper content of foods. Food Standards Committee. London: Her Majesty's Stationery Office.

Matta, J. ; Milad, M. ; Manger, R. ; Torteson, T. (1999). Heavy metals, lipid perocidation and ciguatera toxicity in the liver of the carbbcan barracuda (sphyraena barracuda). Biol. Heavy Elem. Res., 70: 59-79.

Ministry of Food. Food Standards Committee (1953). Report on zinc. London: Her Majesty's Stationery Office.

Misra, B. R. ; Clance, K. A. ; Bare, R. M. ; Waalkes, M. P. (1998). Lack of correlation between the inducibility of metallothionein mRNA and metallothionein protein in Cadmium-exposed rodents. Toxicology, 117: 99-109.

NHMRC, (National Health and Medical Research Council) (1987). National Food Standard A 12: Metals and contaminants in food. Canberra, Australia Australian Government Publishing Service.

Parker, D. ; Turk, J. L. (1978). Delay in the development of the allergic response to metals following intratracheal instillation. Int. Archs. Ailergy Appl. Immun., 57: 289-293.

Rippe, D. F. : Berry. L. J. (1973). Metabolic manifestations of lead acetate sensitization to endotoxin in mice. J. Reticuloendoth. Soc., 13: 527. 
Robert, G. (1991). Toxic effects of metals. In: Casarett and Doull's toxicology. Pergamon Press 662-672.

Thompson, D. R. (1992). Metal levels in marine vertebrates. In: Furness, R. W.: Rainbow, P. S. (Eds.), Heavy metals in the marine environment. CRC Press, Boca Raton, FL, pp. 143-182.

Tolonen, M. (1995). Minerales y oligoelementos. In: Vitaminas y minerals en la salud y la nutriiicion. Acribia, Zaragoza.

Treagan, L. ; Furst, A. (1970). Inhibition of interferon synthesis in mamnalian cell cultures after nickel treatment' Res. Commun. Chem. Path. Pharmacol., 1: 395.

UNEP/FAO/IAEA/IOC, (1984). Sampling of selected marine organisms and sample preparation for trace metal analysis: Reference method for marine pollution studies No. 7, Rev. 2: 19p.

Usero, J. ; Gonzales-Regalado, E. ; Gracia, I. (1996). Trace metals in bivalve molluscs Chamelea gallina from the Atlantic Coast of southern Spain. Mar. Pollut. Bull., 32: 305-310.

Usero, J. ; Gonzales-Regalado, E. ; Gracia, I. (1997). Trace metals in bivalve molluses Ruditapes decussatus and Ruditapes philippincrum from the Atlantic Coast of southern Spain Environ. Int., 23: 291-298.

Yosumura, S. : Vartsky, D. ; Ellis, K. J. ; Cohn, S. H. (1980). Cadmium in human beings; Cadmium in the environment. Nriagu, J. O. ed., Paitz Ecological Cycling. Wiley, New York, pp 12-34. 

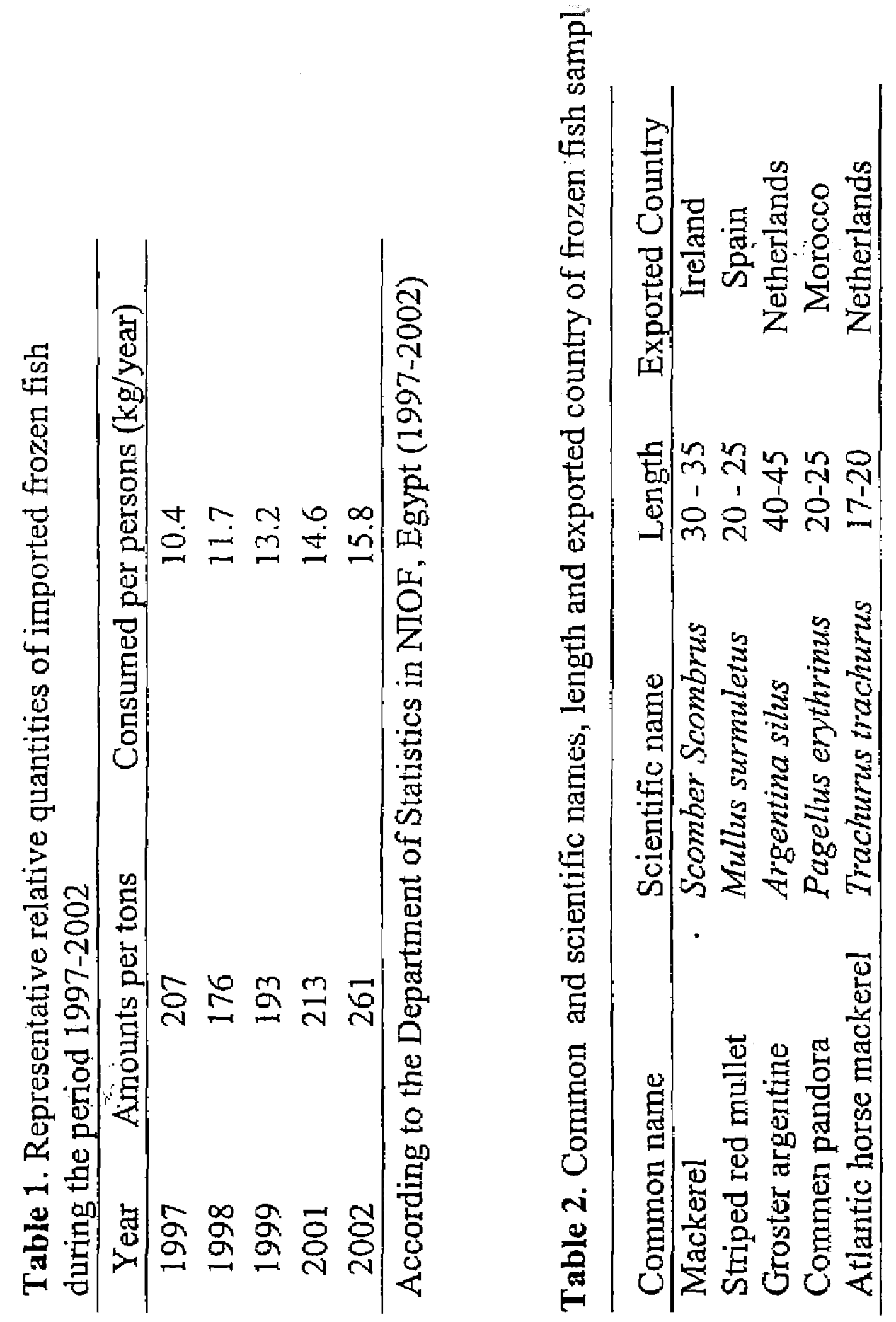


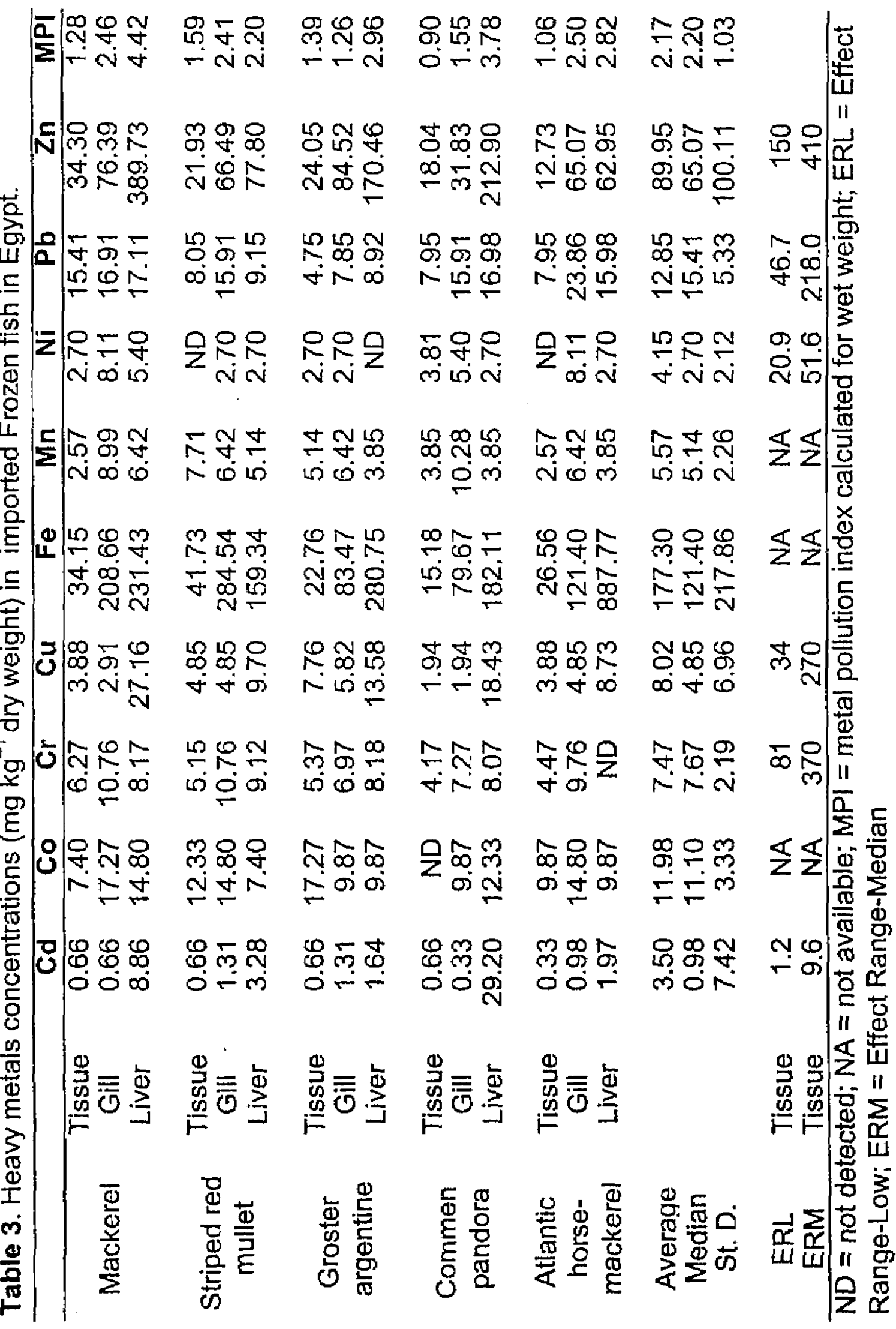




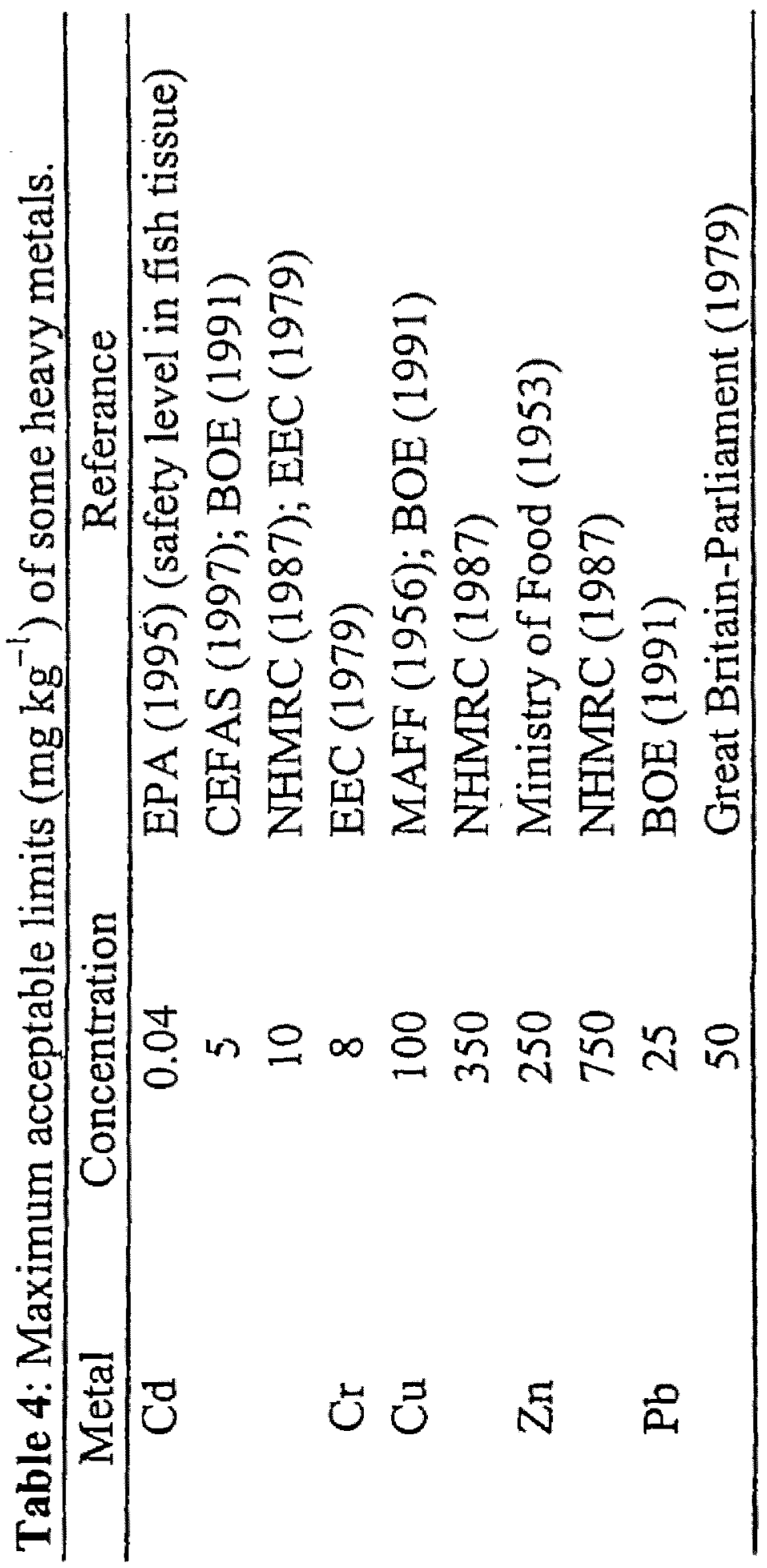




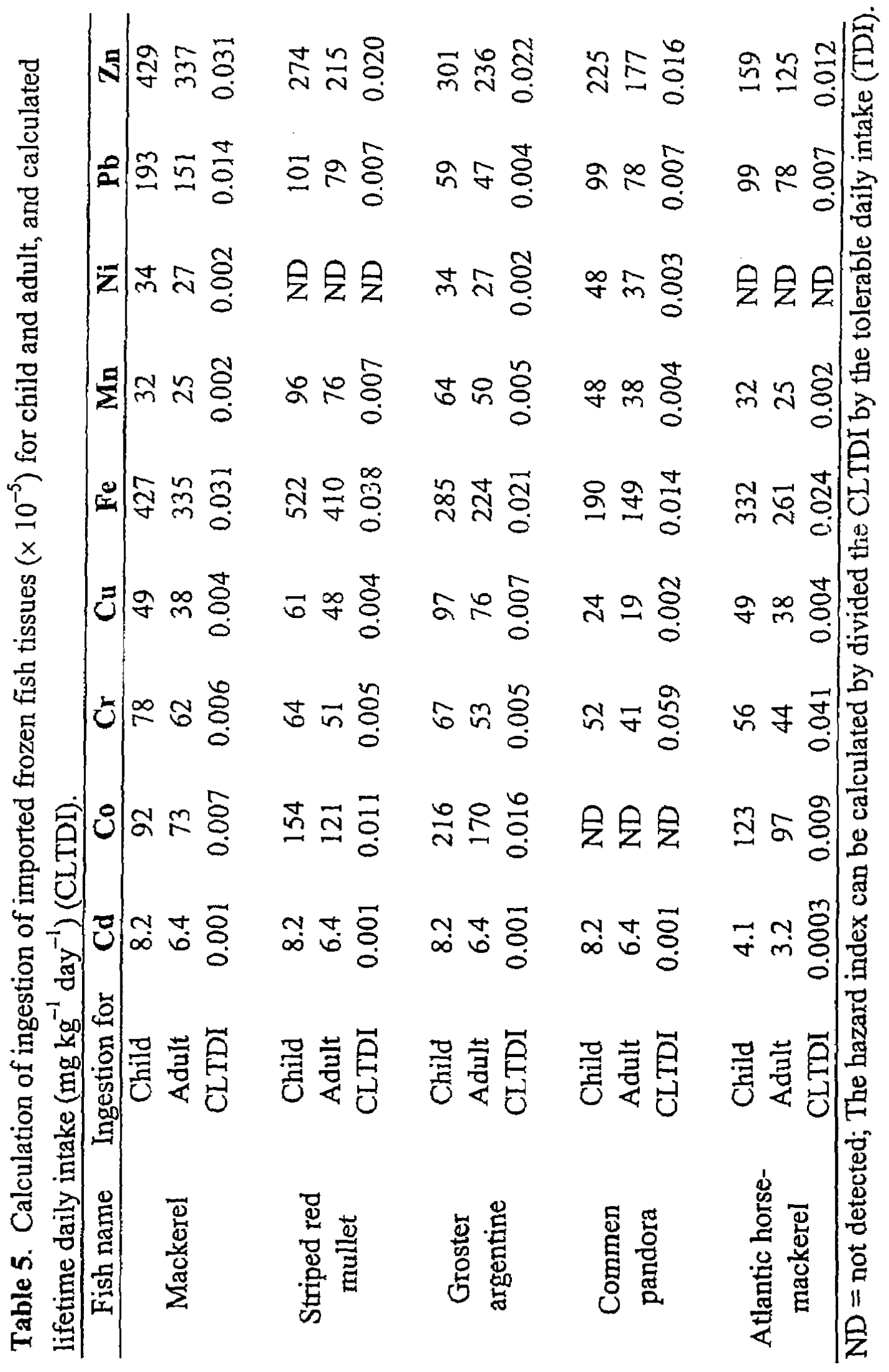

